\title{
A Novel Accessory Protein ArCel5 from Cellulose- Gelatinizing Fungus Arthrobotrys sp. CX1
}

\section{Yue Yuan}

Dalian Polytechnic University

\section{Chunshu Chen}

Dalian Polytechnic University

\section{Xueyan Wang}

Dalian Polytechnic University

\section{Shaonian Shen}

Dalian Polytechnic University

Xiaoyu Guo

Dalian Polytechnic University

\section{Xiaoyi Chen}

Dalian Polytechnic University

\section{Fan Yang}

Dalian Polytechnic University

Xianzhen Li ( $\nabla$ bct-lab@dlpu.edu.cn )

Dalian Polytechnic University

\section{Research Article}

Keywords: accessory protein, CBM, linker, glycosylation, decrystallization, synergism, Escherichia coli, E. coli

Posted Date: January 24th, 2022

DOI: https://doi.org/10.21203/rs.3.rs-1259951/v1

License: (c) (i) This work is licensed under a Creative Commons Attribution 4.0 International License. Read Full License 


\section{Abstract}

Improved understanding of the mechanism of cellulose pretreatment by accessory proteins is beneficial for increasing the hydrolysis efficiency of cellulosic substrates. Here, we report a protein ArCel5 isolated from the cellulosegelatinizing fungus Arthrobotrys sp. CX1. ArCel5 with lower specific hydrolysis activity could effectively disrupt the structure of filter paper and might function as an accessory protein. ArCel5 is a multi-domain protein including a CBM1 family carbohydrate-binding module, a glycosylation linker, and a GH5 family catalytic domain. Based on analyses of adsorption capacity, SEM, hydrature index, FTIR, XRD, and synergistic activity, we demonstrated that CBM1 and linker played an essential role in the binding affinity of the protein and the decrystallization of filter paper, which further encouraged the synergistic action between ArCel5 and cellulases. Notably, glycosylation modification further strengthened the function of the linker region. Overall, the results of this study provide insight into the cellulose decrystallization mechanism of a novel accessory protein ArCel5 that will benefit future applications.

\section{Introduction}

The highly ordered crystalline structure is the bottleneck for effective hydrolysis of cellulosic substrates (Mansfield et al. 2010). Besides engineering cellulases with higher activities (Chundawat et al. 2011; Prajapati et al. 2018), decreasing the crystallinity and increasing the accessibility of cellulose is essential for improving enzymolysis efficiency (Eibinger et al. 2016; Hu et al. 2013; Qin et al. 2013; Song et al. 2018). For this reason, the searching of accessory proteins with effective decrystallization ability is valuable. Mandel and Reese (Reese et al. 1950) previously proposed that a non-hydrolytic swelling factor $\mathrm{C}_{1}$ destroys the crystal structure of cellulose, allowing accessible cellulose to be depolymerized by the hydrolytic enzymes $\left(C_{x}\right)$. At present, a series of $C_{1}$ like accessory proteins, such as LPMO, swolline and expansins, have been proved to loosen and deconstruct the crystalline network of cellulose, facilitating the hydrolysis action of cellulases (Arantes and Saddler 2010; Horn et al. 2012; Payne et al. 2015). However, the main factor influencing the function of accessory protein has not been clearly explained (Arantes and Saddler 2010; Eibinger et al. 2016; Saloheimo et al. 2002).

Many accessory proteins exhibit multi-modularization structure, including a carbohydrate-binding module (CBM) and a catalytic domain connected by a flexible linker (Eibinger et al. 2016; Nikolaos et al. 2015; Saloheimo et al. 2002). CBMs are widely distributed in proteins related to cellulose degradation, and play an essential role in adsorption on insoluble substrates (Gilbert et al. 2013). It is known that CBM and catalytic domain could bind to cellulose, but the affinity of CBM is much higher than that of the catalytic domain (Ståhlberg et al. 1991). Generally, the linker is considered as a disordered polypeptide that maintains the flexibility of protein and connects domains with specific functions (Beckham et al. 2010; Receveur et al. 2002). Usually, the linker is proved to contain more glycosylation sites (Payne et al. 2015; Sammond et al. 2012), which could improve the solubility and stability of the protein (Amore et al. 2017; Gupta et al. 2011). Additionally, recent studies demonstrated that O-glycosylated linker also plays a particular role in the binding process of cellulase and substrate (Amore et al. 2017; Badino et al. 2017; Payne et al. 2013). However, the fundamental effect of the multi-domain structure and post-translational modification on accessory proteins remains unclear.

This study isolated a novel accessory protein ArCel5 from a cellulose-gelatinizing fungus Arthrobotrys sp. CX1. To explain the critical factor that affects the decrystallization ability of accessory proteins, the structure, glycosylation sites, and the cellulose-decrystalling properties of the ArCel5 were analyzed, the effect of CBM and glycosylated linker on the properties of ArCel5 are also investigated and discussed. Our findings should shed light on the molecular mechanism of the cellulose decrystallization process.

\section{Materials And Methods}




\section{Plasmids, strains and culture conditions}

Escherichia col/DH5a was used in all cloning experiments. The plasmid pPICZaA and wild-type Pichia pastorisX-33 were used for the eukaryotic expression of ArCel5 and mutants, whereas the plasmid pET28a and Escherichia coliBL21 (DE3) were ready for the prokaryotic expression of ArCel5. All above plasmids and strains were kind gifts from Prof. Zhao (Dalian Institute of Chemical Physics, CAS). Cellulose-gelatinizing strain Arthrobotrys sp. CX1 was previously isolated by the author's laboratory (Lan et al. 2016) and used in this study for cloning of ArCel5-encoding genes.

Arthrobotrys sp. CX1 was cultivated at $30^{\circ} \mathrm{Cfor} 8-10$ days on the filter paper agar plate (per liter was composed of $2 \mathrm{~g}$ yeast extract and $20 \mathrm{~g}$ agar in the mineral salt solution to produce mineral salt agar plate, and a piece of Whatman filter paper on the mineral salt agar plate). The mineral salt solution (per liter was composed of $2 \mathrm{~g} \mathrm{MgSO}_{4} \cdot 7 \mathrm{H}_{2} \mathrm{O}, 2 \mathrm{~g}$ $\mathrm{Na}_{2} \mathrm{HPO}_{4}, 0.2 \mathrm{~g} \mathrm{FeSO}_{4} \cdot 7 \mathrm{H}_{2} \mathrm{O}, 0.7 \mathrm{~g} \mathrm{CaCl}_{2}$, at pH 6.8-7.0) supplemented with $100 \mathrm{mg}$ of ampicillin and $30 \mathrm{mg}$ of chloramphenicol. Until the translucent paper was observed, a small piece of translucent filter paper $(0.5 \mathrm{~cm} \times 0.5$ $\mathrm{cm}$ ) from the colony edge was transferred into $100 \mathrm{~mL}$ microcrystalline cellulose medium (per liter was composed of 2 $\mathrm{g}$ yeast extract and $10 \mathrm{~g}$ Avicel PH101 microcrystalline cellulose in the mineral salt solution). Then Arthrobotrys sp. CX1 was cultivated at $30^{\circ} \mathrm{C}$ for 7 days in $250 \mathrm{~mL}$ flasks on a rotary shaker incubated at $200 \mathrm{rpm}$. E. coli strains were grown at $37^{\circ} \mathrm{C}$ in LB medium (per liter was composed of $10 \mathrm{~g}$ tryptone, $5.0 \mathrm{~g}$ yeast extract, $10 \mathrm{~g}$ sodium chloride at $\mathrm{pH} 7.0$ ) supplemented with $25 \mu \mathrm{g} / \mathrm{mL}$ zeocin or $100 \mu \mathrm{g} / \mathrm{mL}$ kanamycin if necessary. Pichia pastoris strains were cultured at $30^{\circ} \mathrm{C}$ in YPD medium (per liter was composed of $10 \mathrm{~g}$ yeast extract, $20 \mathrm{~g}$ peptone, $20 \mathrm{~g}$ dextrose, at pH 6.0), BMGY medium (per liter was composed of $3.4 \mathrm{~g}$ YNB, $10 \mathrm{~g}$ ammonium sulfate, $10 \mathrm{~g}$ glycerol, $10 \mathrm{~g}$ yeast extract, $10 \mathrm{~g}$ peptone, $100 \mathrm{~mL}$ of $1 \mathrm{M}$ phosphate buffer, $\mathrm{pH}$ 6.0, and $2 \mathrm{~mL}$ of $200 \mathrm{~g} / \mathrm{L} \mathrm{D}$-biotin), and BMMY medium (identical to BMGY except that it contains $10 \mathrm{~mL} / \mathrm{L}$ of methanol instead of glycerol).

\section{Analysis of the composition of potential accessory protein by MS-based}

Arthrobotrys sp. CX1 was cultured on a filter paper agar plate for 10 days at $30^{\circ} \mathrm{C}$, and the filter paper samples in the degraded area (transparent) and the undegraded area (opaque) were collected and analyzed by SDS-PAGE. The Micro Protein PAGE Recovery Kit (Sangon Biotech, China) was used to recover differentially expressed proteins. The differentially expressed protein was dissolved in a buffer containing $50 \mathrm{mM} \mathrm{Tris-HCl} / 8 \mathrm{M}$ urea ( $\mathrm{pH}$ 8.0). After that, the proteins were reduced by $20 \mathrm{mM}$ DTT at $60^{\circ} \mathrm{C}$ for $1 \mathrm{~h}$, after cool down to room temperature, alkylated by $20 \mathrm{mM}$ IAA at room temperature for $40 \mathrm{~min}$ in the dark, then diluted to $1 \mathrm{M}$ urea by $50 \mathrm{mM}$ Tris- $\mathrm{HCl}$ buffer (pH 8.0). Trypsin (protease concentration $1 \mathrm{mg} / \mathrm{mL}$ ) was added with an enzyme to protein mass ratio of 1:20, and the peptides were obtained by incubation at $37^{\circ} \mathrm{C}$ for $20 \mathrm{~h}$. The tryptic peptides were desalted by the Oasis HLB column (Waters, America) and dissolved in $0.1 \%$ FA after vacuum concentration. Peptides were loaded onto a reversed-phase pre-column (Acclaim PepMap 100, Thermo Scientific), then peptides were separated by an Acclaim PepMapTM RSLC reversed-phase analytical column. The analysis of peptides by using Q-Exactive mass spectrometer equipped with a nanospray ion source and an Ultimate 3000 RSLC nano System. Using MS/MS data obtained by Proteome Discoverer 2.2.0.388. MS identification was performed as described previously (Sun et al. 2019).

\section{Protein sequence analysis and molecular modeling}

Sequence alignment was analyzed by Clustal Omega (Sievers et al. 2011), and the sequence alignment results were output by Espript 3 server (Patrice et al. 2003). The structure of ArCel5 was predicted by using the I-TASSER protein structure homology-modeling online server (http://zhanglab.ccmb.med.umich.edu/I-TASSER/). Models were visualized with PyMOL (http://pymol.sourceforge.net/). The molecular weight of the protein is estimated on the tool page of ExPASy (http://www.expasy.org/tools/). The signal peptide of the gene encoding wild-type ArCel5 was predicted by 
SignalP 4.0 (Petersen et al. 2011). NetOGlyc (http://www.cbs.dtu.dk/services/NetOGlyc/) and NetNGlyc (http://www.cbs.dtu.dk/services/NetNGlyc/) servers were used to predict glycosylation sites.

\section{Expression and purification of ArCel5 and its mutants}

After 7 days cultivated in microcrystalline cellulose medium, the cells of Arthrobotrys sp. CX1 were collected and washed repeatedly with double distilled water. Total RNA of Arthrobotrys sp. CX1 was isolated using RNAiso Plus (TaKaRa Bio Inc., Dalian, China) according to the manufacturer's protocol. The RNA was reverse-transcribed into cDNA using a PrimeScript ${ }^{\mathrm{TM}}$ One Step RT-PCR Kit Ver.2(TaKaRa Bio Inc., Dalian, China)according to the manufacturer's instructions, and the recombinant plasmid was amplified by PCR using PrimeSTAR HS DNA Polymerase (TaKaRa Bio Inc., Dalian, China) and the following primers (Table S1). The native signal peptide of the ArCel 5 was removed from all recombinants. These PCR products of different lengths gene encoding ArCel5 were digested with EcoRI and $X b a l$ and ligated into EcoRI-Xbal-cut pPICZaA to construct recombinant plasmids pPICZaA-ArCel5, pPICZaA-ArCel5-NG, pPICZaAArCel5-LD, pPICZaA-ArCel5-D. The PCR product of arcel5 was digested with EcoRI and HindIII and ligated into EcoRIHindIII-cut pET28a to construct recombinant plasmid pET28a-ArCel5. pPICZaA-ArCel5, pPICZaA-ArCel5-NG, pPICZaAArCel5-LD, pPICZaA-ArCel5-Dafter digested by Sacl, linearized recombinant plasmids were transformed into P. pastoris X-33 to express ArCel5 mutants, respectively. As shown in Fig. 5a, pPICZaA-ArCel5 was used to express ArCel5 (PpArCel5), pPICZaA-ArCel5-NG was used to express the nonglycosylated mutant (Pp-ArCel5-NG) that has a linker with mutation all of the Thr residues to Ala, pPICZaA-ArCel5-LD was used to express a mutant with the removal of CBM1 (Pp-ArCel5-LD), pPICZaA-ArCel5-D was used to express a mutant with the removal of CBM1 and linker (Pp-ArCel5-D),

the above four plasmids after digested by Sacl, linearized recombinant plasmids were transformed into P. pastoris X-33 to express ArCel5 mutants, respectively. pET28a-ArCel5 was transformed into E. coli BL21 (DE3) used to express ArCel5 (Ec-ArCel5). Transformation methods referred to the Invitrogen Pichia pastoris expression manual and pET system operation manual.

For the expression of ArCel5 and its mutants in P. pastoris X-33, the recombinant cells were first grown in $5 \mathrm{~mL}$ YPD medium containing zeocin $(100 \mathrm{mg} / \mathrm{mL})$, then incubated at $30^{\circ} \mathrm{C}$ and $200 \mathrm{rpm}$. After $12 \mathrm{~h}, 0.5 \mathrm{mLcultures}$ were inoculatedto $50 \mathrm{~mL} \mathrm{BMGY}$ medium in $500 \mathrm{~mL}$ shake flasks at $30^{\circ} \mathrm{C}$ and $200 \mathrm{rpm}$ for $16-18 \mathrm{~h}$ until $\mathrm{OD}_{600}$ reached 4.0.Cells were collected by centrifugation at room temperature,resuspended in $200 \mathrm{~mL}$ of BMMY medium in a $2 \mathrm{~L}$ baffled flask,and then incubated at $30^{\circ} \mathrm{C}$ for $96 \mathrm{~h}$. Methanol was added every $24 \mathrm{~h}$ with the final concentration of $1 \%$ $(\mathrm{v} / \mathrm{v})$ to maintain induction of ArCel5.The culture supernatants were collected by centrifugation at $8000 \mathrm{~g}$ for $30 \mathrm{~min}$ at $4^{\circ} \mathrm{C}$. The fermentation supernatant was filtered through a $0.22 \mu \mathrm{m}$ polyethersulfone membrane. The concentrated enzyme solutions were purified by a $10 \mathrm{kDa}$ molecular weight cutoff membrane (Millipore Corporation, USA).

For the expression of ArCel5 in E. coli BL21 (DE3), transformants were grown at $37^{\circ} \mathrm{C}$ in $200 \mathrm{~mL}$ LB medium supplemented with $50 \mathrm{mg} / \mathrm{L}$ kanamycin until $\mathrm{OD}_{600}$ reached 0.5 and induced by adding IPTG at a final concentration of $0.5 \mathrm{mM}$, after which the cells were further cultured at $16^{\circ} \mathrm{C}$ for $14 \mathrm{~h}$. Cells were harvested by centrifugation, and the cell pellet was suspended and sonicated $15 \mathrm{~min}$ on ice for $1 \mathrm{~s}$ with $3 \mathrm{~s}$ intervals in between with an ultrasonic processor. Following the removal of cell debris by centrifugation, the supernatant was ready for subsequent purification. Subsequently, His-tagged proteins were purified by the Ni-NTA purification system using an AKTA Prime Plus (GE Healthcare) as described previously (Crowe 1994).

\section{Comparative analysis by SDS-PAGE}

According to the method described by Laemmli (Laemmli 1970), protein samples were mixed with $5 \times$ loading buffer and incubated at $95^{\circ} \mathrm{C}$ for 10 min prior to being analyzed on $12 \%(\mathrm{w} / \mathrm{v})$ polyacrylamide gel. The gel was stained with coomassie brilliant blue R-250, and the stained protein gel was decolorized with decolorizing solution (5\% ethanol, $10 \%$ 
acetic acid). Glycosylation staining used the Pierce ${ }^{T M}$ Glycoprotein Staining Kit (Thermo Fisher Scientific), following the manufacturer's instructions. Western blot was analyzed as previously reported (Effenberger et al. 2017).

\section{Characterization of binding affinity}

The adsorption experiment was carried out in a $2 \mathrm{~mL}$ tube. Incubate the accessory protein with $10 \mathrm{mg} / \mathrm{mL}$ Avicel and filter paper substrates, which were dissolved in $50 \mathrm{mM}$ acetic acid-sodium acetate buffer (pH 5.0). The protein concentration was $0.1-1 \mathrm{mg} / \mathrm{mL}$, the total volume was $0.5 \mathrm{~mL}$, the adsorption temperature was $25^{\circ} \mathrm{C}$, and the substrate was shaken at $120 \mathrm{rpm}$ for $1 \mathrm{~h}$ to ensure the adequate combination of protein and substrate. Centrifuge (5 min, 12000 $\mathrm{g}$, room temperature) and measure the content of unbound protein with Bio-Rad Protein Assay Kit (Bio-Rad, USA). The Langmuir adsorption isotherms of filter paper and Avicel were selected by appropriate fit $\left(R^{2} \geq 0.98\right)$. To study the role of different domains in binding to cellulose substrate, Pp-ArCel5, Pp-ArCel5-NG, Pp-ArCel5-LD, Pp-ArCel5-D, and cellulose samples were incubated under the same conditions. The adsorbed accessory protein concentration was calculated as the difference between the total protein and the unbound accessory protein concentration. The adsorption isotherm parameters were determined by Langmuir isotherm (Arola and Linder 2016; Eibinger et al. 2016), where $B$ represents the adsorption amount of protein per gram of cellulose $(\mu \mathrm{mol} / \mathrm{g}), B_{\max }$ represents the maximum adsorption amount of protein per gram of cellulose in an equilibrium state $(\mu \mathrm{mol} / \mathrm{g})$, and $K_{\mathrm{d}}$ represents dissociation constant ( $\mu \mathrm{mol} / \mathrm{L})$.

\section{Scanning electron microscopy analysis}

Scanning electron microscopy (SEM) (JEOL, Japan) was applied to the microstructural changes and surface characteristics of Pp-ArCel5 treatment on filter paper. The filter paper used as control were treated with BSA in 50 mM acetic acid-sodium acetate buffer ( $\mathrm{pH}$ 5.0). Before SEM evaluation, the dried samples were coated with a thin layer of gold to prevent the sample from becoming charged under the electron beam.

\section{Enzyme assay}

The specific activity of the enzymes was measured on carboxymethyl cellulose (CMC), Whatman filter paper, cotton, Avicel $\mathrm{PH}-101$, respectively. All reactions were done in $50 \mathrm{mM}$ acetic acid-sodium acetate buffer $(\mathrm{pH} 5.0)$ at $55^{\circ} \mathrm{C}$ for 30 min, and the total reaction volume was $200 \mu \mathrm{L}$. The final concentration of Pp-ArCel5, Pp-ArCel5-NG, Pp-ArCel5-LD, PpArCel5-D used in the assay was $0.1 \mathrm{mg} / \mathrm{mL}$, and substrate concentration was $10 \mathrm{mg} / \mathrm{mL}$. The release of reducing sugar was measured by the 3,5-dinitrosalicylic acid (DNS) method with glucose as a standard (MILLER 1959). One unit of enzyme activity was defined as the amount of enzyme that produced $1 \mu \mathrm{mol}$ reducing sugar per minute.

\section{Hydrature index analysis}

Each protein was applied in $2.5 \mathrm{mg}$ protein per $200 \mathrm{mg}$ of filter paper in $50 \mathrm{mM}$ acetic acid-sodium acetate buffer (pH 5.0) at $5 \mathrm{~mL}$, and the treatment was conducted for $24 \mathrm{~h}$ at $55^{\circ} \mathrm{C}$.After treated with Pp-ArCel5, Pp-ArCel5-NG, Pp-ArCel5LD, Pp-ArCel5-D and BSA respectivily, the morphology of the filter papers was investigated. After removing the enzyme solutionon the surface of the filter paper, the filter paper was weighed as wet weight (Ww). Its dry weight (Wd) was obtained when the treated filter paper was dried at $60^{\circ} \mathrm{C}$ to the constant weight after being washed three times with distilled water. The drying filter paper were abbreviated as $\mathrm{FP}_{\mathrm{WT}}, \mathrm{FP}_{\mathrm{NG}}, \mathrm{FP}_{\mathrm{LD}}, \mathrm{FP}_{\mathrm{CD}}$ and $\mathrm{FP}_{\mathrm{BSA}}$, respectively. The hydrature index (Hyl) (Lan et al. 2016) was calculated as (Eq. 1):

$$
\operatorname{HyI}(\%)=\frac{(W w-W d)}{W d} \times 100
$$


The drying filter paper was subjected to SEM, XRD, FTIR, and synergistic effect analysis separately.

\section{XRD analysis}

The crystalline index of $\mathrm{FP}_{\mathrm{WT}}, \mathrm{FP}_{\mathrm{NG}}, \mathrm{FP}_{\mathrm{LD}}, \mathrm{FP}_{\mathrm{CD}}$ and $\mathrm{FP}_{\mathrm{BSA}}$ were analyzed by $\mathrm{X}$-ray diffraction (XRD) using a Rigaku $\mathrm{D} /$ Max-3B diffractometer (Tokyo, Japan)with Cu Ka radiation $(\lambda=0.154 \mathrm{~nm}) .30 \mathrm{kV}$ accelerating voltage and $30 \mathrm{~mA}$ current. The samples were detected in the range of $2 \theta$ between $5^{\circ}$ and $50^{\circ}$ with a scanning velocity of $2^{\circ} \mathrm{min}^{-1}$. The crystalline index (Crl) (Park et al. 2010) was calculated according to the following equation (Eq. 2):

$$
\operatorname{CrI}(\%)=(1-\text { ham } / \text { her }) \times 100
$$

in which hcr is the peak height at $2 \theta=22.5^{\circ}$ and ham is the peak height at $2 \theta=18^{\circ}$

\section{FTIR analysis}

The Fourier transformed infrared spectroscopy (FTIR) spectral ranges were recorded from 400 to $4000 \mathrm{~cm}^{-1}$ using Spectrum One-B spectrometer (PerkinElmer, USA). 1 mg of $F P_{W T}, F_{N G}, F P_{L D}, F_{C D}$ and $F_{B S A}$ mixing with 100 mg of spectroscopic grade $\mathrm{KBr}$, pressed into pellets and then placed into the plate that was cleaned with acetone twice.Fometer with the detector at $4 \mathrm{~cm}^{-1}$ and 100 scans per sample were signal-averaged and stored.

\section{Synergistic action between Pp-ArCel5 mutants and cellulase}

All reactions were done in $50 \mathrm{mM}$ acetic acid-sodium acetate buffer, $\mathrm{pH} 5.0$, at $55^{\circ} \mathrm{C}$ with shaking $120 \mathrm{rpm}$ over 24

$h$, and the total reaction volume was $200 \mu \mathrm{L}$. The final concentration of $\mathrm{FP}_{\mathrm{WT}}, \mathrm{FP}_{\mathrm{NG}}, \mathrm{FP}_{\mathrm{LD}}, \mathrm{FP}_{\mathrm{CD}}$ and $\mathrm{FP}_{\mathrm{BSA}}$ used in the assay was $10 \mathrm{mg} / \mathrm{mL}$, and Trichoderma reeseicellulase concentration was $20 \mu \mathrm{g} / \mathrm{mg}$ substrate. The FP $\mathrm{BSA}_{\mathrm{BA}}$ treated by fungal cellulase was used as control experiment.

\section{Statistical analysis}

All analyses were performed in triplicate, and the results were shown as the arithmetic mean of values from three repetitions, with standard deviation ( $P$ value $<0.05$ was considered significant).

\section{Results And Discussion}

\section{Isolation of a potential accessory protein}

Previously, a cellulose-gelatinizing fungus Arthrobotrys sp. CX1 was isolated from a soil sample. Arthrobotrys sp. CX1 could make the filter paper translucent by gelatinization, swell the compact structure in filter paper cellulose, reduce the water-assist decrystallization of the crystalline structure by breaking hydrogen bonds, and improve filter paper cellulose degradability. It was speculated that strain CX1 could secrete some accessory proteins in the translucent filter paper that had strong activity on cellulose decrystallization (Lan et al. 2016). To isolate the key accessory protein, Arthrobotrys sp. CX1 was cultured on the filter paper agar plate, secretary proteins in the transparent and opaque areas of filter paper were analyzed using SDS-PAGE. As shown in Fig. 1a, one differential protein band of about $100 \mathrm{kDa}$ was present. After being digested with trypsin, the tryptic peptides of the differential protein were analyzed by LC-MS/MS fragment ion spectra (Fig. 1b). Two sequences TITQTTTF and LTDPRGNMAYEMHQY were preliminarily identified, showing precursor ions at $\mathrm{MH}^{+} 912.5$ and $\mathrm{MH}^{+} 1825.8$ in the MS spectrum (Fig. 1c). Gene of 
the differential protein contains $1269 \mathrm{bp}$, with a GC content of $52.96 \%$. The coding gene of the differential protein was annotated as a hypothetical protein (GenBank: MN654111).

\section{Sequence analysis and homology modeling of ArCel5}

To further speculate the function of the isolated hypothetical protein, sequence analysis and homology modeling were performed. As shown in Fig. 2a, the signal peptide of the hypothetical protein was composed of 19 amino acid residues predicted by Signal P (Version 4.1). The mature protein contained 403 amino acids with a predicted molecular mass of about $44 \mathrm{kDa}$. The hypothetical protein showed the highest identity scores with three characterized glycoside hydrolase family 5 (GH5) enzymes, including 1,4- $\beta$-endoglucanase AnCel5A from Aspergillus niger (accession number AF331518.1, 49\% identity), endoglucanase Ta_Cel5A from Thermoascus aurantiacus (accession number AAL88714.2, $48 \%$ identity), and endoglucanase RBCel 1 from a soil metagenome library in the Antarctic (accession number AC055737, 33\% identity) (Delsaute et al. 2013; Leggio and Larsen 2002; Yan et al. 2016). The secondary structure

prediction of the hypothetical protein revealed a multi-domain structure, consisting of an N-terminal CBM domain (Ala ${ }^{20}$ to $\mathrm{Leu}^{56}$ ), a linker region containing 63 amino acids, and a catalytic domain ( $\mathrm{Phe}^{119}$ to $\mathrm{Leu}^{479}$ ) at the $\mathrm{C}$ terminus. The catalytic domain of the hypothetical protein contained a $(\beta / \alpha) 8$-TIM barrel structure, which was composed of an eightstranded parallel $\beta$-sheet surrounded by eight a-helices (Fig. 2a), indicating a typical structure of the catalytic domains of GH5 family (Payne et al. 2015). Also, E232 and E338 of the central barrel were identified as catalytic residues in the hypothetical protein based on previous analysis (Payne et al. 2015). Therefore, theidentified hypothetical protein was designated as ArCel5.

Homology modeling was performed to predict the typical GH5 structure of ArCel5. The structural superposition of the modeled ArCel5 with AnCel5A (PDB ID: 5i77) revealed that the catalytic domain of ArCel5 is nearly identical to that of $5 i 77$ with a typical GH5 structure (Fig. $2 b$ and 2 c). Sequence analysis showed that ArCel 5 has one more CBM-linker region than three typical GH5 enzymes. The 37 amino acids at the N-terminal of ArCel5 was classified as CBM 1 family mainly derived from fungal cellulase (Guo and Catchmark 2013; Linder et al. 1995), such as the cellobiohydrolase from Trichoderma reesei, which was investigated to bind cellulose substrate through TrCBM1 (PDB ID: 1CBH) (Kraulis et al. 1989; Tomme et al. 1998). Sequence alignment showed that ArCel5-CBM share 69\% identity with TrCBM1, which contains three conserved tyrosines (Fig. 2d and 2e) (Linder et al. 1995). The relatively low sequence identity of the ArCel5 with other enzymes indicated that its function in substrate binding and catalysis may be very different from that of known characterized GH5 enzymes.

\section{ArCel5 is glycosylated at the linker region}

Previous researches revealed that glycosylation modification plays an essential role in the function of glycosidases, especially in enhancing enzyme stability and the binding affinity between proteins and substrates (Amore et al. 2017; Badino et al. 2017; Payne et al. 2013). Here, the glycosylation sites of ArCel5 was predicted by NetOGlyc (http://www.cbs.dtu.dk/services/NetOGlyc/) and NetNGlyc (http://www.cbs.dtu.dk/services/NetNGlyc/) servers. Totally 16 threonine sites in the linker of ArCel5 were identified as candidate O-glycosylation sites, and no N-/O-glycosylation sites were found in the CBM1 and GH5 domains. Differently, highly homologous protein AnCel5A, Ta_Cel5A, RBCel1 are O-glycosylated and N-glycosylated in the GH5 domain, suggesting that ArCel5 might function in different ways.

To further confirm the glycosylation modification existed in ArCel5, two recombinants Pp-ArCel5 and Ec-ArCel5 were heterologously expressed in P. pastoris X-33 and E. coli BL21(DE3), respectively. Compared with Ec-ArCel5, wild-type ArCel5 and Pp-ArCel5 showed higher molecular weight (Fig. 1, Fig. S1), which might be attributed to different posttranslational modification (PTM) levels of proteins among different strains (Amore et al. 2017; Beckham et al. 2012). To verify the location of glycosylation sites, three recombinants including Pp-ArCel5-NG (all the Thr residues in the 
linker were mutated to Ala), Pp-ArCel5-LD (mutant without CBM1) and Pp-ArCel5-D (mutant without both CBM1 and linker) were constructed (Fig. 3a and 3b). Different from Pp-ArCel5-NG and Pp-ArCel5-D, Pp-ArCel5-LD migrated as a diffused band with apparent molecular weight of $75 \mathrm{kDa}$, which was higher than its theoretical molecular weight (Fig. $4 a$ and $4 b$ ). As shown in the glycosylation stained PAGE, both Pp-ArCel5-D and Pp-ArCel5-NG exhibited no stained band, whereas a clear glycoprotein band of Pp-ArCel5-LD could be observed (Fig. 4c). All these results demonstrated that Pp-ArCel5 was strongly glycosylated, and the glycosylation sites were only located in the linker region, which was consistent with the glycosylation prediction result.

\section{CBM1 and glycosylation of linker promote the absorption capacity of Pp-ArCel5}

The adsorption of proteins to cellulose is an essential step for effective pretreatment of cellulose (Johns et al. 2017; Nidetzky et al. 1994). To determine the influence of different domains and glycosylation on the affinity of ArCel5, the adsorption capacity of different recombinants towards cellulosic substrates was analyzed. The fitted Langmuir isotherm results were shown in Fig. S2. and the corresponding parameters were summarized in Table 1. $B_{\max } / K_{\mathrm{d}}$ was applied to quantify the affinity of the protein to cellulose (Arola and Linder 2016; Jarl et al. 2020). The $B_{\max } / K_{\mathrm{d}}$ of PpArCel5 and Pp-ArCel5-NG towards filter paper (Crl $\approx 84 \%)$ was significantly higher than that towards Avicel (Crl $\approx 77 \%)$, due to difference crystallinity of substrates (Hall et al. 2010). Comparatively, no significant difference was observed in $B_{\text {max }} / K_{\mathrm{d}}$ values when Pp-ArCel5-LD and Pp-ArCel5-D were incubated with Avicel PH-101 and filter paper, respectively. These results revealed that CBM1 might belong to type A CBMs that could interact with the multiple planar cellulose chains found in crystalline cellulosic substrates (Hashimoto 2006; Mccartney et al. 2004; McLean and B. 2002), and helped Pp-ArCel5 bind to filter paper with higher crystallinity. The $B_{\max } / K_{d}$ values of Pp-ArCel5, Pp-ArCel5-NG, Pp-ArCel5LD and Pp-ArCel5-D toward both filter paper and Avicel were decreased in turn, suggesting that CBM and the linker could promote the binding affinity of Pp-ArCel5 to cellulosic substrates, and glycosylation of the linker played a positive role in the binding process. Our conclusion was similar with previous studies, which also revealed that CBMs and linker glycosylation facilitate the binding of enzymes toward substrates (Badino et al. 2017; Gilbert et al. 2013; Payne et al. 2015; Payne et al. 2013).

\section{CBM1 and glycosylation of Pp-ArCel5 linker dramatically affect the structure of filter paper}

To preliminarily verify the function of Pp-ArCel5, the microstructure features of filter paper treated by Pp-ArCel5 were observed using SEM. As shown in Fig. 5, after being incubated with Pp-ArCel5, microfibrils in filter paper became dissociated and expanded, creating an amorphic surface and wider width (Fig. 5a, Fig. 5c). The observation was similar to the microstructure of translucent filter paper treated by the strain CX1 (Lan et al. 2016). Differently, after pretreatment with BSA the microfibrils with a smooth surface were not dispersed (Fig. 5b, Fig. 5d). These results indicated that PpArCel5 could disrupt the surface structure of cellulosic substrates. The similar phenomenon was observed previously (Gernot Jäger1† and Rainer Fischer2 2011; Hall et al. 2011). As shown in Table S2, Pp-ArCel5 has lower specific hydrolysis activity on filter paper, cotton, and Avicel than CMC. However, the CMC-hydrolyzing activity of Pp-ArCel5 was lower than that of other endoglucanases in previous reports (Yan et al. 2016). Based on these results, ArCel5 might function as a novel accessory protein.

After being treated by Pp-ArCel5 mutants, the morphology of the filter papers was investigated. As shown in Fig. 6a, the Pp-ArCel5 caused the maximum degree of deagglomeration of the filter paper. Comparatively, Pp-ArCel5-LD and PpArCel5-NG showed weaker swelling activity against the filter paper. There was no significant structural change of filter paper treated by Pp-ArCel5-D or BSA. The result indicated that the deagglomeration ability of ArCel5 against filter paper could be weakened by removing CBM1 or glycosylated linker. The hydrature index (Hyl) values of $F P_{W T}, F_{N G}, F_{L D}$ respectively increased by $89.4 \%, 68.2 \%, 76.5 \%$ in comparison with that of $\mathrm{FP}_{\mathrm{BSA}}$, whereas the Hyl of $\mathrm{FP}_{\mathrm{CD}}$ has no 
significant difference when compared with that of the control (Fig. 6b). The result suggested that both CBM1 and glycosylated linker had a significantly impact on increasing the water absorption capacity of filter paper by Pp-ArCel5. $\mathrm{Hyl}$ results of filter paper treated by different Pp-ArCel5 mutants were in consistent with the morphology investigation, revealing that the water absorption capacity of filter paper caused by Pp-ArCel5 directly related with the deagglomeration degree of filter paper, the similar finding has been reported previously (Lan et al. 2016; Sdrobi et al. 2011; Tsuchida et al. 2014). Moreover, both CBM1 and O-glycosylated linker were essential for the function of PpArCel5.

To further determine the relationship between the water absorption and structure of filter paper after being treated by different Pp-ArCel5 mutants, the FT-IR and XRD were performed. It is known that the increase of hydrogen bonds could enhance the crystallinity and mechanical strength of cellulose (Poletto et al. 2012; Popescu et al. 2011). As shown in Fig. $6 \mathrm{c}$, the absorbance values of the hydrogen-bonded $\mathrm{OH}$ stretching of cellulose varied from 4000 to $2995 \mathrm{~cm}^{-1}$ (Haque et al. 2015), and the characteristic peaks of cellulose crystallization were located at $2900 \mathrm{~cm}^{-1}, 1430 \mathrm{~cm}^{-1}, 1375$ $\mathrm{cm}^{-1}$ regions (Sdrobi et al. 2011). In the FT-IR spectrum, the strongest absorption peaks at $3430 \mathrm{~cm}^{-1}, 2900 \mathrm{~cm}^{-1}, 1430$ $\mathrm{cm}^{-1}$ and $1375 \mathrm{~cm}^{-1}$ of $\mathrm{FP}_{\mathrm{WT}}, \mathrm{FP}_{\mathrm{NG}}, \mathrm{FP}_{\mathrm{LD}}, \mathrm{FP}_{\mathrm{CD}}$ were lower than that of the $\mathrm{FP}_{\mathrm{BSA}}$, which indicated that after being treated by Pp-ArCel5 mutants, the hydrogen bonds of filter paper were reduced, and the structure of filter paper became loose and disordered (Lan et al. 2016; Qin et al. 2013). As shown in Fig. 6d, characteristic peaks at $14.6^{\circ}, 16.4^{\circ}$, and $22.6^{\circ}$ of diffraction angles $2 \theta$ corresponded to $010,10 \overline{1}$, and 002 crystal planes of cellulose I (Eibinger et al. 2016; Hall et al. 2011). After being treated by ArCel5 mutants, no obvious change in peak shape and position of the filter papers could be observed, indicating that the crystal form of the filter papers remained type I structure (Park et al. 2010) (Gang et al. 2011). Compared with the $\mathrm{Crl}$ of $\mathrm{FP}_{\mathrm{WT}}$, the $\mathrm{Crl}$ value of $F P_{L D}, \mathrm{FP}_{\mathrm{NG}}, \mathrm{FP}_{\mathrm{CD}}$ increased in ture when CBM1, glycans and linker were removed from Pp-ArCel5. These finding were also in consistent with the observations in Hyl values and morphology of filter paper, suggesting that Pp-ArCel5 could effectively destroy hydrogen bonds and decrease the crystallinity of filter paper by increasing the water absorption capacity, which further led to significant deagglomeration of filter paper. During this proess, both CBM and glycosylated linker in Pp-ArCel5 palyed important roles. Similar processes have been investigated previously (Gernot Jäger1† and Rainer Fischer2 2011; Qin et al. 2013).

\section{Glycosylation of linker promote the synergism between Pp-ArCel5 and cellulase}

Previous reports showed that the enzymolysis efficiency of cellulose could be affected by the physical structure of the substrate (Kumar and Wyman 2009; Zhang and Lynd 2004). Therefore, the role of CBM and glycosylated linker of PpArCel5 in synergistic action with $T$. reesei cellulase duiring the hydrolysis process of filter paper was investigated. As shown in Fig. 7, compared to the single cellulase hydrolsis system, more reducing sugars were released from filter paper after being incubated with both cellulase and Pp-ArCel5 recombinants. Furthermore, the content of released reducing sugars were reduced in turn when cellulase was cooperated with Pp-ArCel5, Pp-ArCel5-LD, Pp-ArCel5-NG and Pp-ArCel5-D, respectively. The result demonstrated that Pp-ArCel5 could effectively help cellulase to degrade filter paper,

and both CBM and linker in Pp-ArCel5 were essential for this synergistic process. Moreover, the function of linker region was strengthened by glycosylation modification. This investigation could be attributed to our previous speculation that CBM1 and glycosylation of linker dramatically affects the structure of filter paper. According to our knowledge, this is the first report that glycosylation modified linker region could promote the synergistic effect of accessory protein on cellulose hydrolysis.

\section{Conclusions}

ArCel5 is an accessory protein obtained from a cellulose-gelatinizing fungus Arthrobotrys sp. CX1, and probably belongs to a novel protein of the GH5 family. ArCel5 could efficiently disrupt the structure of cellulose and have lower 
specific hydrolysis activity on cellulosic substrates. The CBM1 and linker played key roles in filter paper decrystallization, which could be further strengthened by the glycosylation of the linker. Overall, these results highlight the importance of the multi-domain structure and post-translational modification in accessory protein.

\section{Declarations}

\section{Ethics approval and consent to participate}

Not applicable.

\section{Consent for publication}

Not applicable.

\section{Availability of data and materials}

The dataset (graphs and tables) supporting the conclusions of this article are available.

\section{Competing interests}

The authors declare no conflicts of interest.

\section{Funding}

Financial support for this work was provided by National Natural Science Foundation of China (32072160, 31671796, 31801469), Natural Science Foundation of Liaoning Province (J2020041, 2020-MS-276), and Liaoning BaiQianWan Talents Program was also greatly acknowledged.

\section{Authors' contributions}

Yue Yuan: Methodology, Investigation, Validation, Formal analysis, Writing-Original Draft, Visualization. Chunshu Chen: Investigation, Validation, Formal analysis, Writing-Original Draft. Xueyan Wang: Investigation, Validation, Formal analysis. Shaonian Shen: Investigation, Validation. Xiaoyu Guo: Methodology, Supervision. Xiaoyi Chen: Methodology, Supervision. Fan Yang: Conceptualization, Project administration, Supervision, Methodology, Writing-Review and Editing, Visualization. Xianzhen Li: Resources, Conceptualization, Project administration, Supervision, Data Curation. All authors read and approved the final manuscript.

\section{Acknowledgements}

Not applicable.

\section{References}

1. Amore A, Knott BC, Supekar NT, Shajahan A, Azadi P, Zhao P, Wells L, Linger JG, Hobdey SE, Vander Wall TA (2017) Distinct roles of $\mathrm{N}$ - and $\mathrm{O}-\mathrm{glycans}$ in cellulase activity and stability. Proceedings of the National Academy of Sciences of the United States of America 114(52):13667-13672. https://doi.org/10.1073/pnas.1714249114

2. Arantes V, Saddler JN (2010) Access to cellulose limits the efficiency of enzymatic hydrolysis: the role of amorphogenesis. Biotechnology for Biofuels 3(1):1-11. https://doi.org/10.1186/1754-6834-3-4

3. Arola S, Linder MB (2016) Binding of cellulose binding modules reveal differences between cellulose substrates. Scientific Reports 6:1-9. https://doi.org/10.1038/srep35358 
4. Badino SF, Bathke JK, Sørensen TH, Windahl MS, Jensen K, Peters GHJ, Borch K, Westh P (2017) The influence of different linker modifications on the catalytic activity and cellulose affinity of cellobiohydrolase Cel7A from Hypocrea jecorina. Protein Engineering Design and Selection 30(7) 459-

501. https://doi.org/10.1093/protein/gzx036

5. Beckham GT, Dai Z, Matthews JF, Momany M, Payne CM, Adney WS, Baker SE, Himmel ME (2012) Harnessing glycosylation to improve cellulase activity. Current Opinion in Biotechnology 23(3):338-345. https://doi.org/10.1016/j.copbio.2011.11.030

6. Beckham GT, Bomble YJ, Matthews JF, Taylor CB, Resch MG, Yarbrough JM, Decker SR, Bu L, Zhao X, McCabe C (2010) The O-Glycosylated linker from the Trichoderma reesei family 7 cellulase is a flexible, disordered protein. Biophysical Journal 99(11):3773-3781. https://doi.org/10.1016/j.bpj.2010.10.032

7. Chundawat S, Beckham GT, Himmel ME, Dale BE (2011) Deconstruction of lignocellulosic biomass to fuels and chemicals. Annual review of chemical and biomolecular engineering 2:121-145. https://doi.org/10.1146/annurevchembioeng-061010-114205

8. Crowe J, Dbeli H, Gentz R, Hochuli E, Stber D, Henco K (1994) 6xHis-Ni-NTA chromatography as a superior technique in recombinant protein expression/purification. Methods in Molecular Biology 31:371387. https://doi.org/10.1385/0-89603-258-2:371

9. Delsaute M, Berlemont R, Dehareng D, Van Elder D, Galleni M, Bauvois C (2013) Three-dimensional structure of RBcel1, a metagenome-derived psychrotolerant family GH5 endoglucanase. Acta Crystallographica 69(8):828833. https://doi.org/doi:10.1107/S1744309113014565

10. Effenberger I, Harport M, Pfannstiel J, Klaiber I, Schaller A (2017) Expression in Pichia pastoris and characterization of two novel dirigent proteins for atropselective formation of gossypol. Applied Microbiology and Biotechnology 101(5):2021-2032. https://doi.org/10.1007/s00253-016-7997-3

11. Eibinger M, Sigl K, Sattelkow J, Ganner T, Ramoni J, Seiboth B, Plank H, Nidetzky B (2016) Functional characterization of the native swollenin from Trichoderma reesei : study of its possible role as $\mathrm{C}_{1}$ factor of enzymatic lignocellulose conversion. Biotechnology for Biofuels 9(1):1-19. https://doi.org/10.1186/s13068-0160590-2

12. Cheng G, Varanasi P, P. Varanasi, Liu H, MelnichenkoYB, Simmons BA, Kent MS, Singh S (2011) Transition of cellulose crystalline structure and surface morphology of biomass as a function of ionic liquid pretreatment and its relation to enzymatic hydrolysis. Biomacromolecules 12(4):933-941. https://doi.org/10.1021/bm101240z

13. Jäger G, Girfoglio M, Dollo F, Rinaldi R, Bongard H, Commandeur U, Fischer R, Spiess AC, Büchs J (2011) How recombinant swollenin from Kluyveromyceslactis affects cellulosic substrates and accelerates their hydrolysis. Biotechnology for Biofuels 5(1):1-16. https://doi.org/10.1186/1754-6834-4-33

14. Gilbert HJ, Knox JP, Boraston AB (2013) Advances in understanding the molecular basis of plant cell wall polysaccharide recognition by carbohydrate-binding modules. Current Opinion in Structural Biology 23(5):669677. https://doi.org/10.1016/j.sbi.2013.05.005

15. Guo J, Catchmark JM (2013) Binding specificity and thermodynamics of cellulose-binding modules from Trichoderma reesei Cel7A and Cel6A. Biomacromolecules 14(5):1268-1277. https://doi.org/10.1021/bm300810t

16. Gupta R, Baldock SJ, Fielden PR, Grieve BD (2011) Capillary zone electrophoresis for the analysis of glycoforms of cellobiohydrolase. Journal of Chromatography A 1218(31):5362-

5368. https://doi.org/10.1016/j.chroma.2011.06.036

17. Hall M, Bansal P, Lee JH, Realff MJ, Bommarius AS (2011) Biological pretreatment of cellulose: Enhancing enzymatic hydrolysis rate using cellulose-binding domains from cellulases. Bioresource Technology 102(3):29102915. https://doi.org/10.1016/j.biortech.2010.11.010

Page $11 / 17$ 
18. Hall M, Bansal P, Lee JH, Realff MJ, Bommarius AS (2010) Cellulose crystallinity-a key predictor of the enzymatic hydrolysis rate. Federation of European Biochemical Societies letters 277(6):1571-

1582. https://doi.org/10.1111/j.1742-4658.2010.07585.x

19. Haque MA, Cho KM, Barman DN, Kim MK, Yun HD (2015) A potential cellulose microfibril swelling enzyme isolated from Bacillus sp. AY8 enhances cellulose hydrolysis. Process Biochemistry 50(5):807-

815. https://doi.org/10.1016/j.procbio.2015.02.003

20. Hashimoto H (2006) Recent structural studies of carbohydrate-binding modules. Cellular and Molecular Life Sciences Cmls 63(24):2954-2967. https://doi.org/10.1007/s00018-006-6195-3

21. Horn SJ, Vaaje-Kolstad G, Westereng B, Eijsink VG (2012) Novel enzymes for the degradation of cellulose. Biotechnology for Biofuels 5(1):45-47. https://doi.org/10.1186/1754-6834-5-45

22. Hu J, Arantes V, Pribowo A,Saddler JN (2013) The synergistic action of accessory enzymes enhances the hydrolytic potential of a "cellulase mixture" but is highly substrate specific. Biotechnology for Biofuels 6(1):112. https://doi.org/10.1186/1754-6834-6-112

23. Christensen SJ, Badino SF, Cavaleiro AM, Borch K, Westh P (2020) Functional analysis of chimeric TrCel6A enzymes with different carbohydrate binding modules. Protein Engineering, Design and Selection 32(9):401-409. https://doi.org/10.1093/protein/gzaa003

24. Johns MA, Bernardes A, Azevêdo ERD, Guimares FEG, Lowe JP, Gale EM, Polikarpov I, Scott JL, Sharma RI (2017) On the subtle tuneability of cellulose hydrogels: implications for binding of biomolecules demonstrated for CBM 1. Journal of Materials Chemistry B 5(21):879-3887. https://doi.org/10.1039/c7tb00176b

25. Kraulis PJ, Clore GM, Nilges M, Jones TA, Pettersson G, Knowles J, Gronenborn AM (1989) Determination of the three-dimensional solution structure of the $\mathrm{C}$-terminal domain of cellobiohydrolase I from Trichoderma reesei. A study using nuclear magnetic resonance and hybrid distance geometry-dynamical simulated annealing.

Biochemistry 28(18):7241-7257. https://doi.org/10.1021/bi00444a016

26. Kumar R, Wyman CE (2009) Does change in accessibility with conversion depend on both the substrate and pretreatment technology? Bioresource Technology 99(18):4193-

4202. https://doi.org/10.1016/j.biortech.2008.11.058

27. Laemmli UK (1970) Cleavage of Structural Proteins during the Assembly of the Head of Bacteriophage T4. Nature 227:680-685. https://doi.org/10.1038/227680a0

28. Lan W, Zhang H, Chen X, Yang F, Li X (2016) Gelatinization and decrystallization of cellulose by newly isolated Arthrobotrys sp. CX1 to facilitate cellulose degradability. Cellulose 23(6):3543-

3554. https://doi.org/10.1007/s10570-016-1092-x

29. Leggio LL, Larsen S (2002) The $1.62 \AA$ structure of Thermoascus aurantiacus endoglucanase: completing the structural picture of subfamilies in glycoside hydrolase family 5. Federation of European Biochemical Societies letters 523(1-3):103-108. https://doi.org/10.1016/S0014-5793(02)02954-X

30. Linder M, Lindeberg G, Reinikainen T, Teeri TT, Pettersson G (1995) The difference in affinity between two fungal cellulose-binding domains is dominated by a single amino acid substitution. Federation of European Biochemical Societies letters 372(1):96-98. https://doi.org/10.1016/0014-5793(95)00961-8

31. Mansfield SD, Mooney C, Saddler JN (2010) Substrate and enzyme characteristics that limit cellulose hydrolysis. Biotechnology Progress 15(5): 804-816. https://doi.org/10.1021/bp9900864

32. Mccartney L, Gilbert HJ, Bolam DN, Boraston AB, Knox JP (2004) Glycoside hydrolase carbohydrate-binding modules as molecular probes for the analysis of plant cell wall polymers. Analytical Biochemistry 326(1):49-

54. https://doi.org/10.1016/j.ab.2003.11.011

Page $12 / 17$ 
33. McLean BW, Boraston AB, Brouwer D, Sanaie N, Fyfe CA, Warren RAJ, Kilburn DG, Haynes CA (2002) Carbohydratebinding modules recognize fine substructures of cellulose. Journal of Biological Chemistry 277(52):5024550254. https://doi.org/10.1016/S0009-2614(00)01249-5

34. MILLER GL (1959) Use of Dinitrosalicylic acid reagent for determination of reducing sugar. Analytical Chemistry (31):426-428. https://doi.org/10.1021/ac60147a030

35. Nidetzky B, Steiner W, Claeyssens M (1994) Cellulose hydrolysis by the cellulases from Trichoderma reesei: adsorptions of two cellobiohydrolases, two endocellulases and their core proteins on filter paper and their relation to hydrolysis. Biochemical Journal 303(3):817-823. https://doi.org/10.1042/bj3030817

36. Nikolaos G, Nikolas N, Cosgrove DJ (2015) Bacterial expansins and related proteins from the world of microbes. Applied Microbiology and Biotechnology 99(9):3807-3823. https://doi.org/10.1007/s00253-015-6534-0

37. Park S, Baker JO, Himmel ME, Parilla PA and Johnson DK (2010) Cellulose crystallinity index: measurement techniques and their impact on interpreting cellulase performance. Biotechnology for Biofuels 3(1):110. https://doi.org/10.1186/1754-6834-3-10

38. Patrice G, Xavier R, Emmanuel C (2003) ESPript/ENDscript: Extracting and rendering sequence and 3D information from atomic structures of proteins. Nucleic Acids Research 31(13):3320-3323. https://doi.org/10.1007/s10404008-0309-1

39. Payne CM, Knott BC, Mayes HB, Hansson H, Himmel ME, Sandgren M, Ståhlberg J, Beckham GT (2015) Fungal Cellulases. Chemical Reviews 115(3):1308-1448. https://doi.org/10.1021/cr500351c

40. Payne CM, Resch MG, Chen L, Crowley MF, Himmel ME, Taylor LE, Sandgren M, Ståhlberg J, Stals I, Tan Z, Ståhlberg J (2013) Glycosylated linkers in multimodular lignocellulose-degrading enzymes dynamically bind to cellulose. Proceedings of the National Academy of Sciences of the United States of America 110(36):1464614651. https://doi.org/10.1073/pnas.1309106110

41. Petersen TN, Brunak S, Von HG, Nielsen H (2011) SignalP 4.0: discriminating signal peptides from transmembrane regions. Nature Methods 8(10):785-786. https://doi.org/10.1038/nmeth.1701

42. Poletto M, Zattera AJ, Santana RMC (2012) Structural differences between wood species: Evidence from chemical composition, FTIR spectroscopy, and thermogravimetric analysis. Journal of Applied Polymer Science 126(S1):E337-E344. https://doi.org/10.1002/app.36991

43. Popescu MC, Popescu CM, Lisa G, Sakata Y (2011) Evaluation of morphological and chemical aspects of different wood species by spectroscopy and thermal methods. Journal of Molecular Structure 988(1-3):65-

72. https://doi.org/10.1016/j.molstruc.2010.12.004

44. Prajapati AS, Panchal KJ, Pawar VA, Noronha MJ, Patel DH, Subramanian RB (2018) Review on cellulase and xylanase engineering for biofuel production. Industrial Biotechnology 14(1):38-44.

https://doi.org/10.1089/ind.2017.0027

45. Qin YM, Tao H, Liu YY, Wang YD, Zhang JR,Tang AX (2013) A novel non-hydrolytic protein from Pseudomonas oryzihabitans enhances the enzymatic hydrolysis of cellulose. Journal of Biotechnology 168(1):24-

31. https://doi.org/10.1016/j.jbiotec.2013.07.028

46. Receveur V, Czjzek M, Schulein M, Panine P, Henrissat B (2002) Dimension, shape, and conformational flexibility of a two domain fungal cellulase in solution probed by small angle X-ray scattering. Journal of Biological Chemistry 277(43):40887-40892. https://doi.org/10.1074/jbc.M205404200

47. Reese ET, Siu RGH, Levinson HS (1950) Biological degradation of soluble cellulose derivatives and its relationship to the mechanism of cellulose hydrolysis. Journal of Bacteriology 59(4):485-497. https://doi.org/10.1016/00219169(50)90025-0 
48. Saloheimo M, Paloheimo M, Hakola S, Pere J, Swanson B, Nyyssönen E, Bhatia A, Ward M, Penttilä M (2002) Swollenin, a Trichoderma reesei protein with sequence similarity to the plant expansins, exhibits disruption activity on cellulosic materials. European Journal of Biochemistry 269(17):4202-4211. https://doi.org/10.1046/j.14321033.2002.03095.x

49. Sammond DW, Payne CM, Roman B, Himmel ME, Crowley MF, Beckham GT (2012) Cellulase linkers are optimized based on domain type and function: insights from sequence analysis, biophysical measurements, and molecular simulation. Plos One 7(11):1-14, https://doi.org/10.1371/journal.pone.0048615

50. Sdrobi A, Cazacu G, Totolin M, Vasile C (2011) Alkaline solution swelling of fatty acids-modified softwood Kraft pulp fibers under cold plasma conditions. Cellulose Chemistry and Technology 45(5-6):329-

338. https://doi.org/10.1007/s10570-011-9519-x

51. Sievers F, Wilm A, Dineen D, Gibson TJ, Karplus K, Li W, Lopez R, Mcwilliam H, Remmert M, Söding J, Thompson JD, Higgins DG (2011) Fast, scalable generation of high-quality protein multiple sequence alignments using Clustal Omega. Molecular Systems Biology 7(1):1-6. https://doi.org/10.1038/msb.2011.75

52. Song B, Li B, Wang X, Shen W, Park S, Collings C, Feng A, Smith SJ, Walton JD, Ding SY (2018) Real-time imaging reveals that lytic polysaccharide monooxygenase promotes cellulase activity by increasing cellulose accessibility. Biotechnology for Biofuels 11(1):1-11. https://doi.org/10.1186/s13068-018-1023-1

53. Ståhlberg J, Johansson G, Pettersson G (1991) A new model for enzymatic hydrolysis of cellulose based on the two-domain structure of cellobiohydrolase I. Nature Biotechnology 9(3):286-290. https://doi.org/10.1038/nbt0391286

54. Sun Z, Liu H, Wang X, Yang F, Li X (2019) Proteomic analysis of the xanthan-degrading pathway of Microbacterium sp. XT11. ACS Omega 4(21):19096-19105, https://doi.org/10.1021/acsomega.9b02313

55. Tomme P, Boraston A, Mclean B, Kormos J, Creagh AL, Sturch K, Gilkes NR, Haynes CA, Warren RAJ, Kilburn DG (1998) Characterization and affinity applications of cellulose-binding domains. Journal of Chromatography B, Biomedical Sciences and Applications 715(1):283-296. https://doi.org/10.1016/S0378-4347(98)00053-X

56. Tsuchida JE, Rezende CA, Oliveira-Silva R, Lima MA, d’Eurydice MN, Polikarpov I, Bonagamba TJ (2014) Nuclear magnetic resonance investigation of water accessibility in cellulose of pretreated sugarcane bagasse. Biotechnology for Biofuels 7(1):1-13. https://doi.org/10.1186/s13068-014-0127-5

57. Yan J, Liu W, Li Y, Lai H, Zheng Y, Huang J, Chen C, Chen Y, Jin J, Li H (2016) Functional and structural analysis of Pichia pastoris-expressed Aspergillus niger 1,4- $\beta$-endoglucanase. Biochemical and Biophysical Research Communications 475(1):8-12. https://doi.org/10.1016/j.bbrc.2016.05.012

58. Zhang YHP, Lynd LR (2004) Toward an aggregated understanding of enzymatic hydrolysis of cellulose: Noncomplexed cellulase systems. Biotechnology and Bioengineering 88(7):797824. https://doi.org/10.1002/bit.20282

\section{Tables}

Table 1 Adsorption parameters of ArCel5 constructions on Avicel pH-101 and filter paper. 


\begin{tabular}{|c|c|c|c|c|c|c|c|c|}
\hline \multirow[t]{2}{*}{ Substrate } & \multicolumn{4}{|c|}{ Avicel pH-101 } & \multicolumn{4}{|c|}{ Filter paper } \\
\hline & ArCel5 & $\begin{array}{l}\text { ArCel5- } \\
\text { LD }\end{array}$ & $\begin{array}{l}\text { ArCel5- } \\
\text { NG }\end{array}$ & ArCel5-D & ArCel5 & $\begin{array}{l}\text { ArCel5- } \\
\text { LD }\end{array}$ & ArCel5-NG & ArCel5-D \\
\hline$B_{\max }(\mu \mathrm{mol} / \mathrm{g})$ & $0.25 \pm 0.03$ & $0.18 \pm 0.01$ & $0.33 \pm 0.10$ & $0.12 \pm 0.00$ & $0.34 \pm 0.03$ & $0.15 \pm 0.00$ & $0.46 \pm 0.022$ & $0.21 \pm 0.00$ \\
\hline$K_{\mathrm{d}}(\mu \mathrm{M})$ & $0.48 \pm 0.11$ & $2.08 \pm 0.30$ & $1.41 \pm 0.19$ & $2.53 \pm 0.24$ & $0.27 \pm 0.05$ & $1.79 \pm 0.19$ & $1.08 \pm 0.11$ & $2.04 \pm 0.19$ \\
\hline $\begin{array}{l}\text { Absolute } \\
\text { specificity (L/g) }\end{array}$ & 0.52 & 0.09 & 0.23 & 0.05 & 1.26 & 0.083 & 0.43 & 0.10 \\
\hline a & & & & & & & & \\
\hline $\begin{array}{l}\text { Relative } \\
\text { specifity b }\end{array}$ & 10.4 & 1.8 & 4.6 & 1 & 12.6 & 0.83 & 4.3 & 1 \\
\hline
\end{tabular}

$B_{\max }$ maximum binding capacity, $K_{\mathrm{d}}$ dissociation constant.

a $B_{\max } / K_{\mathrm{d}}$

${ }^{\mathrm{b}}$ Absolute specificities normalized on ArCel5-D.

\section{Figures}

\section{Figure 1}

Isolation of ArCel5. (a) The decrystallization phenomenon on filter paper agar plate caused by the growth of cellulosegelatinizing fungus Arthrobotrys sp.CX1. (b) The different secretary proteins between opaque area and the transparent area were assessed by SDS-PAGE. Lanes 1-2 showed the total proteins of the opaque area in the filter paper sample. Lanes 3-4 showed the total proteins of the transparent area in the filter paper sample. The arrow indicates a differential protein band found only in the transparent region. (c) LC-MS/MS fragment ion spectra of the peptides in the arrow area. The peptide TITQTTTF and LTDPRGNMAYEMHQY were distinguished and identified.

\section{Figure 2}

Sequence and structure properties of ArCel5. (a) Alignment of amino acid sequences of ArCel5 (GenBank accession number MN654111), Ta_Cel5A (GenBank accession number AAL88714.2), AnCel5A (GenBank accession number AF331518.1) and RBCel1(GenBank accession number AC055737). The signal peptide (dotted line), family 1 carbohydrate binding molecule (gray full line) and linker peptide (black full line) of ArCel5 were also marked. The amino acid residues conserved in all four proteins are shown with white letters and black boxes, and the amino acid residues conserved in two or three differential protein are shown with highlighted in gray, and the secondary structure is shown above the sequence. Sequence alignment was analyzed by ClustalOmega (Petersen et al. 2011), and results were output by Espript 3 server (Patrice et al. 2003). (b) ArCel5 structure was shown in a cartoon model with the CBM, linker, and $C D$ domain in blue, gray and orange, respectively. (c) A structural overlay of the modeled ArCel5 with AnCel5A (PDB entry 5i77) was made to allow visual comparison. (d) Structure comparison of TrCBM1 (PDB entry $1 \mathrm{CBH}$, orange) with ArCel5-CBM (blue). (e) ArCel5-CBM and TrCBM1 could form a flat binding surface with cellulose, and the three 
conserved tyrosines were shown in yellow and gray, respectively. The structure homology-modeling of ArCel5 was predicted by using I-TASSER online server (http://zhanglab.ccmb.med.umich.edu/l-TASSER/).

\section{Figure 3}

Rational design of ArCel5 mutants. (a) Sequences of the linker regions from the 67 th base to the 108th base. (b) Constructions of the mutants with variable lengths.

\section{Figure 4}

SDS-PAGE analysis of ArCel5 mutants. (a) Coomassie stain, (b) Western-Blot analyses of Pp-ArCel5. (c) Glycoprotein stain. Lanes 1: Pp-ArCel5-LD; lanes 2: Pp-ArCel5-NG; lanes 3: Pp-ArCel5-D.

\section{Figure 5}

Scanning electron microscopy of filter paper after treated by different solutions. Pictures with two different scale markers were taken at $\times 500$ and $\times 2500$ magnifications. (a, c) Filter paper treated by BSA in 50 mM acetic acid-sodium acetate buffer ( $\mathrm{pH}$ 5.0) with different magnification. (b, d) Filter paper treated by Pp-ArCel5 in $50 \mathrm{mM}$ acetic acidsodium acetate buffer ( $\mathrm{pH}$ 5.0) with different magnification. The final concentration of filter paper with $40 \mathrm{~g} / \mathrm{L}$ was incubated in $50 \mathrm{mM}$ acetic acid-sodium acetate buffer (pH 5.0), containing $0.5 \mathrm{~g} / \mathrm{L} \mathrm{Pp-ArCel5}$ or BSA at $55^{\circ} \mathrm{C}$ for $24 \mathrm{~h}$.

\section{Figure 6}

(a) Filter paper was deconstructed by ArCel5 mutants. Pp-ArCel5, Pp-ArCel5-NG, Pp-ArCel5-D or BSA acted on filter paper for $48 \mathrm{~h}$ to observe disruption. The filter paper with a size of $1 \mathrm{~cm} \times 2 \mathrm{~cm}$ was incubated in $50 \mathrm{mM}$ acetic acidsodium acetate buffer (pH 5.0), containing $0.5 \mathrm{~g} / \mathrm{L}$ ArCel5 mutants or BSA at $55^{\circ} \mathrm{C}$ for $24 \mathrm{~h}$.

(b) The hydrature index of filter paper after treated by ArCel5 mutants and BSA. The different letters mean significant difference, during the same letter means no significant difference. The final concentration of filter paper with $40 \mathrm{~g} / \mathrm{L}$ was incubated in $50 \mathrm{mM}$ acetic acid-sodium acetate buffer ( $\mathrm{pH} 5.0$ ) containing $0.5 \mathrm{~g} / \mathrm{L}$ ArCel5 mutants or $\mathrm{BSA}$ at $55^{\circ} \mathrm{C}$ for $24 \mathrm{~h}$.

(c) FTIR spectroscopy spectrum of the filter paper after being treated by the ArCel5 mutants or BSA.

(d) The X-ray diffraction spectrum imbibed of the filter paper after being treated by ArCel5 mutants and BSA.

\section{Figure 7}

The synergy between ArCel5 mutants and fungal cellulase in the hydrolysis of filter paper. All reactions were done in 50 $\mathrm{mM}$ acetic acid-sodium acetate buffer $(\mathrm{pH} 5.0)$ at $55^{\circ} \mathrm{C}$ with shaking $120 \mathrm{rpm}$ over $24 \mathrm{~h}$. The final concentration of filter 
paper treated in different ways was all $10 \mathrm{mg} / \mathrm{mL}$, and Trichoderma reesei cellulase was $20 \mu \mathrm{g} / \mathrm{mg}$ substrate. The $\mathrm{FP}_{\mathrm{BSA}}$ treated by fungal cellulase was used as reference experiment. Error bars show the standard deviation of three independent experiments.

\section{Supplementary Files}

This is a list of supplementary files associated with this preprint. Click to download.

- GraphicalAbstract.pdf

- Supplementarymaterial.docx 